\title{
Survival of Chemically Modified Titanium Surfaced Implants in Irradiated Jaws of Oral Cancer Patients
}

\author{
Mehmet Yaltirik1, Bilge Gökçen Röhlig², Meltem Özdemir Karataş², Melike Ordulu Sübay ${ }^{*}$, \\ Rüştü Cem Tanyel ${ }^{1}$, Meltem Koray ${ }^{1}$ \\ ${ }^{1}$ Department of Oral and Maxillofacial Surgery, Faculty of Dentistry, Istanbul University, Istanbul, Turkey \\ ${ }^{2}$ Department of Prosthodontics, Faculty of Dentistry, Istanbul University, Istanbul, Turkey \\ Email: ${ }^{*}$ melikeordulu@yahoo.com
}

Received 28 May 2015; accepted 14 July 2015; published 17 July 2015

Copyright (C) 2015 by authors and Scientific Research Publishing Inc.

This work is licensed under the Creative Commons Attribution International License (CC BY).

http://creativecommons.org/licenses/by/4.0/

c) (†) Open Access

\section{Abstract}

Objective: To investigate the clinical performance of implants with chemically modified surfaces in irradiated bone in a period of five-years. Patients \& Methods: 15 ( 6 females, 9 males, 50.2 years with a range of 38 - 60 years) patients who had been operated for oral tumors and had undergone radiotherapy were enrolled and 40 SLActive surface implants were placed (24 in the maxilla, 16 in the mandible). Implants were allowed to integrate for a period of 90 days and the stability of the implants was measured with Resonance Frequency Analyzer/Osstell ${ }^{\mathrm{TM}}$ Mentor (Integration Diagnostics, Savedalen, Sweden) at implant placement, 30 days later and at the end of the $90^{\text {th }}$ day. Patients follow up periods after the implant placement varied from 20 months to 60 months (mean: 45 months). Results: Two implants were lost in maxilla in healing period as a result of osseointegration failure. The survival rate was $95 \%$. During the observation period, totally $4 \mathrm{im}$ plants were lost. The overall success rate was $90 \%$. 3 of the lost implants were in maxilla and one was in mandible. The initial ISQ values of the implants differed from 20 - 71; the second values were between $24-71$ and the last values were between $30-89$. The implants which were lost could not show a value greater than 35 . Conclusion: There was no any complication on the SLActive surface implant placed bones due to irradiation. Within the limitations of this study, it may be concluded that osseointegrated implants can be placed in irradiated bones, unless a careful patient selection and treatment planning is performed.

\section{Keywords}

Irradiation, Resonance Frequency Analysis, SLActive, Success Criteria

\footnotetext{
${ }^{*}$ Corresponding author.
} 


\section{Introduction}

Rehabilitation of patients with head and neck cancer usually involves ablative surgery, chemotherapy, radiotherapy or a combination of these modalities. The surgical treatment often results in clinical situations where prosthetic treatment is mandatory and conventional rehabiliation does not produce satisfactory results. In such cases, use of osseointegrated implants can improve the final outcome of the restorations.

Irradiation leads to progressive fibrosis of blood vessels, alteration in vascular supply of structures and decrease in osteoblastic and osteoclastic activity in surrounding bone [1]. Osteonecrosis and soft tissue dehiscences are further complications encountered in irradiated patients undergoing oral surgical procedures. Although success of osseointegration of implants depends on the bone density, surgical technique and the microscopic and macroscopic morphology of the implants, the survival and the success rates are markedly reduced in irradiated fields. Such a result is explained with reduced bone vitality [2] [3]. Most studies demonstrated that reduction of implant stability in alveolar bone at 8 weeks after implant placement was due to impaired integration that arose from lack of remodeling and reduced bone vascularity [4] [5]. In these cases, there is considerable interest in enhancing the quality and rate of bone formation around dental implants. This formation of new bone can be actively influenced by implant surface properties.

Since the beginning of 1980s, many efforts have been made to improve osseointegration and the amount of bone to implant contact [6]-[10]. Additions of a layer of hydroxyapatite on to the titanium, and plasma-spray coating of the implant body are the common methods for surface modifications and they have been proven to have successful long-term rates. Recently a new chemically modified, sandblasted large grit and acid-etched (SLActive) active and hydrophilic implant surface has been introduced to enhance bone apposition (SLActive, Straumann, AG, Basel, Switzerland). With the use of a specific surface production process (after the titanium surfaces were processed with etch, they were rinsed with $\mathrm{N} 2$ protection and stored in an isotonic $\mathrm{NaCl}$ solution) standard SLA surfaces were converted into a chemically active surface containing hydrocarbons and carbonates. This active hydroxylated/hydrated surface was shown to have an initial advancing water contact angle of $0^{\circ}$ and this resulted in an ultra hydrophilic character. Histological studies have also shown that SLActive implants exhibited a significantly greater bone-to-implant contact than conventional SLA surfaces at 2 and 4 weeks of healing [9] [11] [12]. These preliminary studies suggest that SLActive surfaces might also help to improve the stability of implants placed in irradiated bone. If this newly developed surface could produce predictable results, then the prosthetic rehabilitation of head and neck cancer patients may be improved.

Therefore, the aim of the present pilot study was to investigate clinically the osseointegration course of the chemically modified titanium surfaces (SLActive) in irradiated bone.

\section{Patients and Methods}

This study was approved by the Ethical Committee of the Istanbul University, Medical School of Istanbul (nr. 2007/1032). All participating individuals signed an informed consent.

The patients were selected consecutively among the patients referred to the Department of Maxillofacial Prosthodontics, Faculty of Dentistry, Istanbul University for prosthetic restoration. Fourty implants placed in 15 patients with maxillofacial defects caused by tumor resections of oral cancers at a university clinic between 1989 and 2005 were included in the study. They had been operated because of oral cancer and received radiation for tumors. Chemically modified surfaced implants (SLActive Straumann ${ }^{\circledR}$, AG, Waldenburg, Switzerland) were placed by the same oral surgeon in irradiated bones.

The inclusion criteria for enrollment in this study were: 1) patients who had been operated for oral tumors and fallowed at least 5 years for metastasis 2) patients who had undergone radiotherapy in areas including future implant sides, 3) a period of minimum 12 months following radiotherapy. The exclusion criteria of study were patients who had been subject to bone-grafting procedures were excluded.

A comprehensive treatment plan was presented to each of the patients based on clinical and radiographic findings, specialty consultations with head and neck surgeon, oncologist and oral surgeon. After consultations, placement of osseointegrated SLActive surface implants was planned.

All patients received an antibiotic therapy using clindamycin $300 \mathrm{mg}$ three times daily pre and postoperatively (1 day preoperatively and 3 days postoperatively). The surgical procedure was conducted in 2 stage with general guidelines defined by Brånemark et al. and the specific indications that were recommended by Buser et al. for Straumann Dental Implants. Totally 40 SLActive implants (24 maxilla, 16 mandible) (Straumann AG, Walden- 
burg, Switzerland) were placed. The demographic and treatment data of the patients are listed in Table 1.

Implants were allowed to integrate for a period of 90 days and the stability of the implants was measured with Resonance Frequency Analyzer (RFA)/Osstell ${ }^{\mathrm{TM}}$ Mentor (Integration Diagnostics, Savedalen, Sweden) at implant placement, 30 days later and at the end of the $90^{\text {th }}$ day and if the measurements were not high enough for an abutment connection, measurements were performed monthly until satisfactory results were gained. RFA values are recorded in Implant Stability Quotient (ISQ) ranging from 1 to 100. ISQ values are derived from the stiffness $(\mathrm{N} / \mu \mathrm{m})$ of the implant/bone system and the calibration parameters of the transducer. High ISQ value indicates high stability, whereas low value indicates a low implant stability. All of the implants' measurements were high enough for an abutment connection at the end of the $3^{\text {rd }}$ month.

Prosthetic treatment of the patients was performed by the same prosthodontist. Locater abutments (Zest Anchors, Inc., California, USA, Distributor; Institut Straumann AG Basel, Switzerland) were used to assist with retention of the obturators, dolder bar was used to retain mandibular resection prosthesis.

All participants received digital (Morita Veraview IC5 ${ }^{\circledR}$, J Morita MFG Corp, Kyoto, Japan) or analog panoramic radiographs (Planmeca ${ }^{\circledR}$, Proline XC, Helsinki, Finland) using the imaging equipment preoperatively, immediately after surgery, immediately after loading and at scheluded appointments for the evaluation of marginal bone levels of the implants.

\section{Results}

The study population consisted of 15 patients (6 female 9 male). 11 patients had been operated because of squamous cell carcinoma while the others had been treated because of epidermoid carcinoma.

Of the forty implants, 24 implants were placed in the maxilla, 16 were placed in the mandible. All implants had a diameter of $4.1 \mathrm{~mm}$ and the lengths are $8 \mathrm{~mm}(\mathrm{n}=1)$ to $10 \mathrm{~mm}(\mathrm{n}=23)$ and $12 \mathrm{~mm}(\mathrm{n}=16)$. The mean age at the implant placement was 50.2 years with a range of 38 - 60 years.

All implants were placed in radiated bone. The radiation doses varied from $30 \mathrm{~Gy}(\mathrm{n}=3)$ to $40 \mathrm{~Gy}(\mathrm{n}=11)$ and $120 \mathrm{~Gy}(\mathrm{n}=1)$. Time from the last radiotherapy session to implant placement differs from 12 months to 28 months. None of the patients had recurrences of their tumors at the end of the follow up periods.

The initial ISQ values of the implants differs from 20 - 71 at the time of the operation. The second measurement was made at the $30^{\text {th }}$ day and the values were measured between $24-71$. At $90^{\text {th }}$ day after the operation the

Table 1. The demographic and treatment data of the patients.

\begin{tabular}{|c|c|c|c|c|c|c|c|c|c|c|c|c|}
\hline & Gender & Age & $\begin{array}{l}\text { Tumor } \\
\text { type }\end{array}$ & $\begin{array}{l}\text { Time of cancer } \\
\text { diagnosis and } \\
\text { medical history }\end{array}$ & $\begin{array}{l}\text { Surgical } \\
\text { treatment }\end{array}$ & $\begin{array}{l}\text { Radiation } \\
\text { dose }\end{array}$ & $\begin{array}{l}\text { N. of } \\
\text { implants } \\
\text { inserted }\end{array}$ & $\begin{array}{l}\text { Location of } \\
\text { implants }\end{array}$ & $\begin{array}{c}\text { Implant } \\
\text { dimensions }\end{array}$ & $\begin{array}{l}\text { N. of } \\
\text { imp. lost }\end{array}$ & $\begin{array}{l}\text { Time from } \\
\text { end of RT } \\
\text { to imp. } \\
\text { placement }\end{array}$ & Follow-up \\
\hline 1 & Male & 58 & $\begin{array}{l}\text { Squamous } \\
\text { cell } \\
\text { carsinoma }\end{array}$ & $\begin{array}{c}\text { Diagnosed in } \\
\text { 1972, operated } \\
\text { in } 1972,1976 \\
\text { and } 1989\end{array}$ & $\begin{array}{l}\text { Partial right } \\
\text { maxillectomy } \\
\quad \text { (in 1989) }\end{array}$ & $\begin{array}{c}40 \text { Gy } \\
\text { (postoperative) }\end{array}$ & 3 & $\begin{array}{c}\text { Premaxilla } \\
\text { and premolar } \\
\text { region }\end{array}$ & $\begin{array}{l}1(3.3 \times 10) \\
2(4.1 \times 12)\end{array}$ & None & $\begin{array}{c}18 \\
\text { months }\end{array}$ & $\begin{array}{c}60 \\
\text { months }\end{array}$ \\
\hline 2 & Male & 50 & $\begin{array}{l}\text { Squamous } \\
\text { cell } \\
\text { carsinoma }\end{array}$ & $\begin{array}{l}\text { Diagnosed and } \\
\text { operated in } 2001 \text {, } \\
\text { till then no } \\
\text { metastases or } \\
\text { recurrence }\end{array}$ & $\begin{array}{c}\text { Partial left } \\
\text { maxillectomy }\end{array}$ & $\begin{array}{c}120 \text { Gy and } \\
\text { received } \\
\text { chemotherapy } \\
\text { (postoperative). }\end{array}$ & 3 & $\begin{array}{c}\text { Premaxilla } \\
\text { and premolar } \\
\text { region }\end{array}$ & $\begin{array}{c}2(4.1 \times 10) \\
1(4.1 \times 8)\end{array}$ & $\begin{array}{l}1 \text { (in } \\
\text { premolar } \\
\text { region) }\end{array}$ & $\begin{array}{c}21 \\
\text { months }\end{array}$ & $\begin{array}{c}48 \\
\text { months }\end{array}$ \\
\hline 4 & Female & 60 & $\begin{array}{l}\text { Squamous } \\
\text { cell } \\
\text { carsinoma }\end{array}$ & $\begin{array}{c}\text { Diagnosed and } \\
\text { operated in } 2002 \\
\text { till then no } \\
\text { metastases or } \\
\text { recurrence }\end{array}$ & $\begin{array}{c}\text { Partial left } \\
\text { maxillectomy }\end{array}$ & $\begin{array}{c}40 \text { Gy } \\
\text { (postoperative) }\end{array}$ & 2 & $\begin{array}{l}\text { Premaxilla } \\
\text { and tuber } \\
\text { region }\end{array}$ & $\begin{array}{c}1(4.1 \times 10) \\
1(4.1 \times 12)\end{array}$ & None & $\begin{array}{c}18 \\
\text { months }\end{array}$ & $\begin{array}{c}60 \\
\text { months }\end{array}$ \\
\hline
\end{tabular}




\section{Continued}

\begin{tabular}{|c|c|c|c|c|c|c|c|c|c|c|c|c|}
\hline 5 & Male & 38 & $\begin{array}{l}\text { Epidermoid } \\
\text { carcinoma }\end{array}$ & $\begin{array}{c}\text { Diagnosed and } \\
\text { operated in } 2002 \\
\text { till then no } \\
\text { metastases or } \\
\text { recurrence }\end{array}$ & $\begin{array}{l}\text { Segmental } \\
\text { resection of } \\
\text { mandible }\end{array}$ & $\begin{array}{c}30 \text { Gy } \\
\text { (postoperative) }\end{array}$ & 2 & $\begin{array}{c}\text { Intra-foraminal } \\
\text { region }\end{array}$ & $2(4.1 \times 12)$ & None & $\begin{array}{c}18 \\
\text { months }\end{array}$ & $\begin{array}{c}40 \\
\text { months }\end{array}$ \\
\hline 6 & Male & 45 & $\begin{array}{l}\text { Squamous } \\
\text { cell } \\
\text { carsinoma }\end{array}$ & $\begin{array}{l}\text { Diagnosed and } \\
\text { operated in 2002, } \\
\text { till then no } \\
\text { metastases or } \\
\text { recurrence }\end{array}$ & $\begin{array}{l}\text { Partial right } \\
\text { maxillectomy }\end{array}$ & $\begin{array}{c}40 \text { Gy } \\
\text { (postoperative) }\end{array}$ & 2 & $\begin{array}{l}\text { Premaxilla } \\
\text { and premolar } \\
\text { region }\end{array}$ & $\begin{array}{l}1(4.1 \times 10) \\
1(4.1 \times 12)\end{array}$ & None & $\begin{array}{c}20 \\
\text { months }\end{array}$ & $\begin{array}{c}60 \\
\text { months }\end{array}$ \\
\hline 7 & Female & 50 & $\begin{array}{l}\text { Squamous } \\
\text { cell } \\
\text { carsinoma }\end{array}$ & $\begin{array}{l}\text { Diagnosed and } \\
\text { operated in } 2001 \text {, } \\
\text { till then no } \\
\text { metastases or } \\
\text { recurrence }\end{array}$ & $\begin{array}{c}\text { Partial left } \\
\text { maxillectomy }\end{array}$ & $\begin{array}{c}40 \text { Gy } \\
\text { (postoperative) }\end{array}$ & 3 & $\begin{array}{l}\text { Premaxilla } \\
\text { and premolar } \\
\text { region }\end{array}$ & $\begin{array}{c}2(4.1 \times 10) \\
1(4.1 \times 12)\end{array}$ & None & $\begin{array}{c}26 \\
\text { months }\end{array}$ & $\begin{array}{c}60 \\
\text { months }\end{array}$ \\
\hline 8 & Male & 42 & $\begin{array}{l}\text { Epidermoid } \\
\text { carcinoma }\end{array}$ & $\begin{array}{l}\text { Diagnosed and } \\
\text { operated in } 2000 \\
\text { and till then no } \\
\text { metastases or } \\
\text { recurrence }\end{array}$ & $\begin{array}{l}\text { Segmental } \\
\text { resection of } \\
\text { mandible } \\
\text { (resection of } \\
\text { left posterior) }\end{array}$ & $\begin{array}{c}40 \text { Gy } \\
\text { (postoperative) }\end{array}$ & 2 & $\begin{array}{l}\text { Premaxilla } \\
\text { on defect } \\
\text { side }\end{array}$ & $\begin{array}{l}1(4.1 \times 10) \\
1(4.1 \times 12)\end{array}$ & None & $\begin{array}{c}18 \\
\text { months }\end{array}$ & $\begin{array}{c}60 \\
\text { months }\end{array}$ \\
\hline 9 & Male & 56 & $\begin{array}{l}\text { Squamous } \\
\text { cell } \\
\text { carsinoma }\end{array}$ & $\begin{array}{l}\text { Diagnosed and } \\
\text { operated in } 2002 \\
\text { till then no } \\
\text { metastases or } \\
\text { recurrence }\end{array}$ & $\begin{array}{l}\text { Partial right } \\
\text { maxillectomy }\end{array}$ & $\begin{array}{c}40 \mathrm{~Gy} \\
\text { (postoperative) }\end{array}$ & 2 & $\begin{array}{l}\text { Premaxilla } \\
\text { and tuber } \\
\text { region }\end{array}$ & $\begin{array}{l}1(4.1 \times 10) \\
1(4.1 \times 12)\end{array}$ & $\begin{array}{c}1 \text { (in } \\
\text { canine } \\
\text { region) }\end{array}$ & $\begin{array}{c}28 \\
\text { months }\end{array}$ & $\begin{array}{c}60 \\
\text { months }\end{array}$ \\
\hline & Female & 44 & $\begin{array}{l}\text { Squamous } \\
\text { cell } \\
\text { carsinoma }\end{array}$ & $\begin{array}{l}\text { Diagnosed and } \\
\text { operated in } 2002 \\
\text { till then no } \\
\text { metastases or } \\
\text { recurrence }\end{array}$ & $\begin{array}{l}\text { Partial right } \\
\text { maxillectomy }\end{array}$ & $\begin{array}{c}40 \text { Gy } \\
\text { (postoperative) }\end{array}$ & 2 & $\begin{array}{c}\text { Intra-foraminal } \\
\text { region }\end{array}$ & $2(4.1 \times 12)$ & None & $\begin{array}{c}12 \\
\text { months }\end{array}$ & $\begin{array}{c}60 \\
\text { months }\end{array}$ \\
\hline & Female & 52 & $\begin{array}{l}\text { Squamous } \\
\text { cell } \\
\text { carsinoma }\end{array}$ & $\begin{array}{l}\text { Diagnosed and } \\
\text { operated in 2004, } \\
\text { till then no } \\
\text { metastases or } \\
\text { recurrence }\end{array}$ & $\begin{array}{l}\text { Partial right } \\
\text { maxillectomy }\end{array}$ & $\begin{array}{c}40 \text { Gy } \\
\text { (postoperative) }\end{array}$ & 4 & $\begin{array}{l}\text { Premaxilla } \\
\text { and premolar } \\
\text { region }\end{array}$ & $\begin{array}{l}2(4.1 \times 10) ; \\
2(4.1 \times 12)\end{array}$ & $\begin{array}{c}1 \text { (in } \\
\text { canine } \\
\text { region) }\end{array}$ & $\begin{array}{c}18 \\
\text { months }\end{array}$ & $\begin{array}{c}24 \\
\text { months }\end{array}$ \\
\hline 12 & Male & 46 & $\begin{array}{l}\text { Squamous } \\
\text { cell } \\
\text { carsinoma }\end{array}$ & $\begin{array}{l}\text { Diagnosed and } \\
\text { operated in } 2004 \text {, } \\
\text { till then no } \\
\text { metastases or } \\
\text { recurrence }\end{array}$ & $\begin{array}{l}\text { Segmental } \\
\text { resection of } \\
\text { mandible } \\
\text { (resection of } \\
\text { left posterior) }\end{array}$ & $\begin{array}{c}40 \text { Gy } \\
\text { (postoperative) }\end{array}$ & 3 & $\begin{array}{c}\text { Intra-foraminal } \\
\text { region }\end{array}$ & $\begin{array}{c}2(4.1 \times 10) \\
1(4.1 \times 12)\end{array}$ & None & $\begin{array}{c}20 \\
\text { months }\end{array}$ & $\begin{array}{c}24 \\
\text { months }\end{array}$ \\
\hline 13 & Male & 48 & $\begin{array}{l}\text { Epidermoid } \\
\text { carcinoma }\end{array}$ & $\begin{array}{l}\text { Diagnosed and } \\
\text { operated in } 2000 \\
\text { and till then no } \\
\text { metastases or } \\
\text { recurrence }\end{array}$ & $\begin{array}{l}\text { Mandible } \\
\text { Alveolar } \\
\text { resection }\end{array}$ & $\begin{array}{c}40 \text { Gy } \\
\text { (postoperative) }\end{array}$ & 3 & $\begin{array}{c}\text { Intra-foraminal } \\
\text { region }\end{array}$ & $3(4.1 \times 10)$ & None & $\begin{array}{c}18 \\
\text { months }\end{array}$ & $\begin{array}{c}20 \\
\text { months }\end{array}$ \\
\hline 14 & Female & 56 & $\begin{array}{l}\text { Epidermoid } \\
\text { carcinoma }\end{array}$ & $\begin{array}{l}\text { Diagnosed and } \\
\text { operated in } 2005 \\
\text { and till then no } \\
\text { metastases or } \\
\text { recurrence }\end{array}$ & $\begin{array}{l}\text { Segmental } \\
\text { resection of } \\
\text { mandible } \\
\text { (resection of } \\
\text { right posterior) }\end{array}$ & $\begin{array}{c}40 \mathrm{~Gy} \\
\text { (postoperative) }\end{array}$ & 2 & $\begin{array}{c}\text { Intra-foraminal } \\
\text { region }\end{array}$ & $2(4.1 \times 10)$ & None & $\begin{array}{c}18 \\
\text { months }\end{array}$ & $\begin{array}{c}20 \\
\text { months }\end{array}$ \\
\hline 15 & Male & 60 & $\begin{array}{l}\text { Squamous } \\
\text { cell } \\
\text { carsinoma }\end{array}$ & $\begin{array}{l}\text { Diagnosed and } \\
\text { operated in } 2005 \\
\text { and till then no } \\
\text { metastases or } \\
\text { recurrence }\end{array}$ & $\begin{array}{l}\text { Mandible } \\
\text { Alveolar } \\
\text { resection }\end{array}$ & $\begin{array}{c}30 \text { Gy } \\
\text { (postoperative) }\end{array}$ & 4 & $\begin{array}{l}\text { Premolar and } \\
\text { intraforaminal } \\
\text { region }\end{array}$ & $4(4.1 \times 10)$ & $\begin{array}{l}1 \text { (in } \\
\text { premolar } \\
\text { region) }\end{array}$ & $\begin{array}{c}20 \\
\text { months }\end{array}$ & $\begin{array}{c}20 \\
\text { months }\end{array}$ \\
\hline
\end{tabular}


measurements were renewed and the minimum score was 30 while the highest score was measured 89. The implants which were lost could not showed a value greater than 35.

Patients follow up periods after the implant placement varied from 20 months to 60 months (mean 45 months).

\subsection{Implant Success, Survival Rate}

Two implants were lost in maxilla in healing period as a result of osseointegration failure. The survival rate was 95\%. During the observation period, totally 4 implants (3 in maxilla, 1 in mandible) were lost. 37 implants were regarded as successful according to the criteria proposed by Misch et al. [9] and overall success rate was $90 \%$.

\subsection{The Marginal Bone Loss}

The mean marginal bone loss (MBL) was $1.2 \mathrm{~mm}$ on the mesial side and $1.4 \mathrm{~mm}$ on the distal side of the implants. The MBL on the distal and mesial aspects of the implants up to 48 mo to 60 mo following loading did not exceed $2 \mathrm{~mm}$.

No patient reported low satisfaction and oral health related quality of life scores (score lower than 50) [13].

\section{Discussion}

Patients with oral cancer need multidisciplinary approach from the beginning of their therapies. Surgeons, radiation and medical oncologists and dental specialists involving this process. Oral cancer therapy contains three main stages such as surgery, radiotherapy and chemotherapy. Of the three modalities surgery is most commonly used. Resection of the tumoral tissue is the main aim of the cancer therapy. The formed defect size after surgical intervention can range from a small soft tissue deformity to a large defect where significant amounts of maxilla or mandible are lost. In these kinds of patients, achieving the prosthetic stability is the main goal of the dental treatment and dental implants are playing an important role in achieving this aim [14]. The use of dental implants in oral cancer patients is being increased day to day [15] [16].

Most of the oral cancer patients take radiation therapy in the course of their rehabilitation. It is known that can have a negative effect on implant survival [17] [18]. During treatment, irradiated bone change properties, with loss of bone quality and vasculature. Additionally, the quantity of doses has been shown to be very important for bone recovery after treatment [19]. Some researchers analyzed the comparison between the radiation dose and the implant success and its stated that the amount of the dose directly effect on the implant stability [13] [17] [20]. Visch et al. [20] had shown that lower radiation dose ( $<50 \mathrm{~Gy})$ is associated with significantly improved implant survival than in patients after irradiation with a higher dose ( $>50 \mathrm{~Gy})$. In this study we could not confirm these statements because most of the patients received radiotherapy less than 50 Gy. Only one patient received a radiation dose of $120 \mathrm{~Gy}$ and lost one of the three implants which was in peremolar region in maxilla.

Histological studies have also shown that SLActive implants exhibited a significantly greater bone-to-implant contact than conventional SLA surfaces at 2 and 4 weeks of healing [9] [11] [12]. In the present study there was no any complication on the SLActive surface implant placed bones due to irradiation and the overall success rate was $90 \%$ regarding implant success.

The time of the implant placement after the last radiotherapy session may contribute to the success or failure of osseointegration. In literature different studies have investigated the required time interval between radiotherapy and implant installation that may influence osseointegration [21]-[24]. Marx and Johnson [25] reported that the probability of implant failure is higher in cases where dental implants are inserted between one and six months following radiotherapy. Cao et al. [21] shared the same findings where the dental implants installed 6 months following radiation showed significantly lower implant survival rate. In Visch's [20] study, they stated that there is no significant difference in survival of implants inserted less than 12 months (76\%) or at least one year (81\%) after radiotherapy. Werkmeister et al. [26] found osteointegration is negatively influenced in dental implants that installed 2 years following end of radiotherapy. But in mentioned study the implant survival rate of the implants which were in non-irradiated bone was also low (68\%). In our study the implant placement time differs from 12 months to 28 months. Remarkably, one of the 4 implants that we have lost installed in $28^{\text {th }}$ month after radiation in the maxilla in canine region.

Resonance frequency analysis is a reliable and reproducible standardized method measuring implant stability. 
Differences in implant stability can be recorded in vivo at insertion of an implant and during the course of osseointegration [27] [28]. ISQ values may range from 0 to 100. Successfully integrated implants have ISQ values above 40 [27] [29]-[34]. Verdonk et al. [27] reported that in 2008, immediately after placement, ISQ values were not statistically significant different in irradiated and non-irradiated alveolar bone. But at 8 weeks after implant placement, they found a statistically significant difference in ISQ value. ISQ values of 16 and 24 weeks after implant placement showed a stabilization or even slight increase when compared with the values of 8 weeks after implant placement. They also report that primary stability depends on bone density. But after the implant placement, the stability depends on osteointegration. In our study we prefer to measure implant stability at the time of implant placement, $30^{\text {th }}$ day and $90^{\text {th }}$ day after the operation. Our results are most likely the Verdonk and his friends results but most of the implants that include our study showed slight continuous rate of increase ISQ values during the 90 days.

The success of osseointegrated implants depends on the bone density, surgical technique and on the microscopic and macroscopic morphology of the implants used. Studies in animals shown that the chemically modified SLActive surface furnished the adhesion and stabilization of the blood clot in early hours following implant placement. In early days osteoblast differentiation and vascular structures can be observed in the connective tissue that formed around the implant [17] [35]. Compared with the SLA implant surface, SLActive implant surface has shown significant higher levels in ALP (alkaline phosphatase) expression as well as early osteocalsin synthesis [17] [36]. In addition to these findings Schwarz et al. [12] and Buser et al. [9] reported that the bone implant contact rate was significantly higher in SLActive implants after 7 and 14 days. If its taken in consideration that most implant failures seen in irradited patients occurred shortly after implant placement in the early period between primary and secondary stability in bone as reported by the researchers, using SLActive surface implants could be useful in these kind of individuals [13] [18] [37] [38]. There are many investigations in the literature aiming to evaluate the survival of dental implants in patients with oral cancers. If we take a look at previous studies about this topic we can encounter different outcomes. Some authors stated that, dental implant supported prosthesis have significantly lower survival rates in irradiated patients compared to non-irradiated patients. Visch et al. [20] reported after a 14 years follow up period implant survival (78\%) is significantly influenced by location, extent of surgery and by the irradiation dose at the implant site. Cao and Weicher's [21] and Werkmeister's [26] findings supports this conclusion and they found the implant survival rates in irradiated bones in turn (88\%) and (68.8\%). On the other hand, most of the researchers conclude their investigations by the statement that dental implants can osseointegrate and can remain functionally stable in patients having undergone radiotherapy [16] [17] [22] [23]. After 60 months period our cumulative survival rate is 90\%. 36 of 40 implants that we include in the study were functionally stable.

\section{Conclusion}

Although the survival and success rates of implants were slightly lower than standard conditions, from the results of this pilot study, it may be concluded that SLActive surface implants can be placed in irradiated bones, unless a careful patient selection and treatment planning is performed. Studying with larger case numbers will help gather more information about the success of SLActive surface implants as a treatment of modality in maxillofacial defects patients, with irradiated bones.

\section{References}

[1] Hu, W.W., Ward, B.B., Wang, Z. and Krebsbach, P.H. (2010) Bone Regeneration in Defects Compromised by Radiotherapy. Journal of Dental Research, 89, 77-81. http://dx.doi.org/10.1177/0022034509352151

[2] Wang, R., Pillai, K. and Jones, P.K. (1998) Dosimetric Measurements of Scatter Radiation from Dental Implants in Stimulated Head and Neck Radiotherapy. International Journal of Oral Maxillofacial Implants, 13, 197-203.

[3] Grotz, K.A., Al-Nawas, B., Piepkorn, B., Reichert, T.E., Duschner, H. and Wagner, W. (1999) Micromorphological Findings in Jaw Bone after Radiotherapy. Mund-, Kiefer- und Gesichtschirurgie, 3, 140-145.

[4] Yerit, K., Posch, M., Seemann, M., Hainich, S., Dortbudak, O., Turhani, D., Ozyuvaci, H., Watzinger, R. and Ewers, R. (2006) Implant Survival in Mandibles of Irradiated Oral Cancer Patients. Clinical Oral Implants Research, 17, 337344. http://dx.doi.org/10.1111/j.1600-0501.2005.01160.x

[5] Verdonck, H.W.D., Meijer, G.J., Laurin, T., Nieman, F.H.M., Stoll, C., Riediger, D., Stoelinga, P.J.W. and de Baat, C. (2007) Assessment of Vascularity in Irradiated and Non-Irradiated Maxillary and Mandibular Alveolar Minipig Bone 
Using Laser Doppler Flowmetry. International Journal of Oral Maxillofacial Implants, 22, 774-778.

[6] Buser, D., Schenk, R.K., Steinemann, S., Fiorellini, J.P., Fox, C.H. and Stich, H. (1991) Influence of Surface Characteristics on Bone Integration of Titanium Implants. Journal of Biomedical Materials Research, 25, 889-902. http://dx.doi.org/10.1002/jbm.820250708

[7] Nicolucci, B. (1993) Dental Implants: The Blade Implant. Oral Health, 83, 55-56.

[8] Shen, T.C. (1999) The Use of Different Implant Modalities in the Atrophied Ridge. Journal of Oral Implantology, 25, 109-113. http://dx.doi.org/10.1563/1548-1336(1999)025<0109:TUODIM>2.3.CO;2

[9] Buser, D., Broggini, N., Wieland, M., Schenk, R.K., Denzer, A.J., Cochran, D.L., Hoffmann, B., Lussi, A. and Steinemann, S.G. (2004) Enhanced Bone Apposition to a Chemically Modified SLA Titanium Surface. Journal of Dental Research, 83, 529-533. http://dx.doi.org/10.1177/154405910408300704

[10] Schliephake, H., Aref, A., Scharnweber, D., Bierbaum, S. and Sewing, A. (2009) Effect of Modifications of Dual AcidEtched Implant Surfaces on Peri-Implant Bone Formation. Part I: Organic Coatings. Clinical Oral Implants Research, 20, 31-37. http://dx.doi.org/10.1111/j.1600-0501.2008.01603.x

[11] Ferguson, S.J., Broggini, N., Wieland, M., de Wild, M., Rupp, F., Geis-Gerstorfer, J., Cochran, D.L. and Buser, D. (2006) Biomechanical Evaluation of the Interfacial Strength of a Chemically Modified Sandblasted and Acid-Etched Titanium Surface. Journal of Biomedical Materials Research Part A, 78, 291-297. http://dx.doi.org/10.1002/jbm.a.30678

[12] Schwarz, F., Herten, M., Sager, M., Wieland, M., Dard, M. and Becker, J. (2007) Histological and Immunohistochemical Analysis of Initial and Early Osseous Integration at Chemically Modified and Conventional SLA Titanium Implants: Preliminary Results of a Pilot Study in Dogs. Clinical Oral Implants Research, 18, 481-488. http://dx.doi.org/10.1111/j.1600-0501.2007.01341.x

[13] Colella, G., Cannavale, R., Pentenero, M. and Gandolfo, S. (2007) Oral Implants in Radiated Patients: A Systematic Review. The International Journal of Oral \& Maxillofacial Implants, 22, 616-622.

[14] Barrowman, R.A., Wilson, P.R. and Wiesenfeld, D. (2011) Oral Rehabilitation with Dental Implants after Cancer Treatment. Australian Dental Journal, 56, 160-165. http://dx.doi.org/10.1111/j.1834-7819.2011.01318.x

[15] Cuesta-Gil, M., Ochandiano Caicoya, S., Riba-García, F., Duarte Ruiz, B., Navarro Cuéllar, C. and Navarro Vila, C. (2009) Oral Rehabilitation with Osseointegrated Implants in Oncologic Patients. Journal of Oral and Maxillofacial Surgery, 67, 2485-2496. http://dx.doi.org/10.1016/j.joms.2008.03.001

[16] McGhee, M.A., Stern, S.J., Callan, D., Shewmake, K. and Smith, T. (1997) Osseointegrated Implants in the Head and Neck Cancer Patient. Head \& Neck, 19, 659-665. http://dx.doi.org/10.1002/(SICI)1097-0347(199712)19:8<659::AID-HED3>3.0.CO;2-4

[17] Heberer, S., Kilic, S., Hossamo, J., Raguse, J.D. and Nelson, K. (2011) Rehabilitation of Irradiated Patients with Modified and Conventional Sandblasted Acid-Etched Implants: Preliminary Results of a Split-Mouth Study. Clinical Oral Implants Research, 22, 546-551. http://dx.doi.org/10.1111/j.1600-0501.2010.02050.x

[18] Granström, G. (2005) Oseointegration in Irradiated Cancer Patients: An Analysis with Respect to Implant Failures. Int Journal of Oral and Maxillofacial Surgery, 63, 579-585. http://dx.doi.org/10.1016/j.joms.2005.01.008

[19] Asikainen, P., Klemetti, E., Kotilainen, R., Vuillemin, T., Sutter, F., Voipio, H.M. and Kullaa, A. (1998) Osseointegration of Dental Implants in Bone Irradiated with 40, 50 or 60 Gy Doses. An Experimental Study with Beagle Dogs. Clinical Oral Implants Research, 9, 20-25. http://dx.doi.org/10.1034/j.1600-0501.1998.090103.x

[20] Visch, L.L., van Waas, M.A.J., Schmitz, P.I.M. and Levendag, P.C. (2002) A Clinical Evaluation of Implants in Irradiated Oral Cancer Patients. Journal of Dental Research, 81, 856-859. http://dx.doi.org/10.1177/154405910208101212

[21] Cao, Y. and Weischer, T. (2003) Comparison of Maxillary Implant-Supported Prosthesis in Irradiated and NonIrradiated Patients. Journal of Huazhong University of Science and Technology-Medical Sciences, 23, $209-212$.

[22] Schoen, P.J., Raghoebar, G.M., Bouma, J., Reintsema, H., Burlage, F.R., Roodenburg, J.L., et al. (2008) Prosthodontic Rehabilitation of Oral Function in Head-Neck Cancer Patients with Dental Implants Placed Simultaneously during Ablative Tumour Surgery: An Assessment of Treatment Outcomes and Quality of Life. International Journal of Oral and Maxillofacial Surgery, 37, 8-16. http://dx.doi.org/10.1016/j.ijom.2007.07.015

[23] Schoen, P.J., Raghoebar, G.M., Bouma, J., Reintsema, H., Vissink, A., Sterk, W., et al. (2007) Rehabilitation of Oral Function in Head and Neck Cancer Patients after Radiotherapy with Implant-Retained Dentures: Effects of Hyperbaric Oxygen Therapy. Oral Oncology, 43, 379-388. http://dx.doi.org/10.1016/j.oraloncology.2006.04.009

[24] August, M., Bast, B., Jackson, M. and Perrott, D. (1998) Use of the Fixed Mandibular Implant in Oral Cancer Patients: A Retrospective Study. Journal of Oral and Maxillofacial Surgery, 56, 297-301. http://dx.doi.org/10.1016/S0278-2391(98)90102-1 
[25] Marx, R.E. and Johnson, R.P. (1987) Studies in the Radiobiology of Osteoradionecrosis and Their Clinical Significance. Oral Surgery, Oral Medicine, Oral Pathology, 64, 379-390. http://dx.doi.org/10.1016/0030-4220(87)90136-8

[26] Werkmeister, R., Szulczewski, D., Walteros-Benz, P. and Joos, U. (1999) Rehabilitation with Dental Implants of Oral Cancer Patients. Journal of Cranio-Maxillofacial Surgery, 27, 38-41. http://dx.doi.org/10.1016/S1010-5182(99)80008-0

[27] Verdonck, H.W., Meijer, G.J., Laurin, T., Nieman, F.H., Stoll, C., Riediger, D., Stoelinga, P.J. and de Baat, C. (2008) Implant Stability during Osseointegration in Irradiated and Non-Irradiated Minipig Alveolar Bone: An Experimental Study. Clinical Oral Implants Research, 19, 201-206. http://dx.doi.org/10.1111/j.1600-0501.2007.01457.x

[28] Meredith, N., Shagaldi, F., Alleyne, D., Sennerby, L. and Cawley, P. (1997) The Application of Resonance Frequency Measurements to Study the Stability of Titanium Implants during Healing in the Rabbit Tibia. Clinical Oral Implants Research, 8, 234-243. http://dx.doi.org/10.1034/j.1600-0501.1997.080310.x

[29] Balleri, P., Cozzolino, A., Ghelli, L., Momicchioli, G. and Varriale, A. (2002) Stability Measurements of Osseointegrated Implants Using Osstell in Partially Edentulous Jaws after 1 Year of Loading: A Pilot Study. Clinical Implant Dentistry and Related Research, 4, 128-132. http://dx.doi.org/10.1111/j.1708-8208.2002.tb00162.x

[30] Olsson, M., Urde, G., Andersen, J.B. and Sennerby, L. (2003) Early Loading of Maxillary Cross-Arch Dental Prostheses Supported by Six or Eight Oxidized Titanium Implants: Results after 1 Year of Loading, Case Series. Clinical Implant Dentistry and Related Research, 5, 81-87. http://dx.doi.org/10.1111/j.1708-8208.2003.tb00019.x

[31] Farzad, P., Andersson, L., Gunnarssson, S. and Sharma, P. (2004) Implant Stability, Tissue Conditions, and Patient Self-Evaluation after Treatment with Osseointegrated Implants in the Posterior Mandible. Clinical Implant Dentistry and Related Research, 6, 24-32. http://dx.doi.org/10.1111/j.1708-8208.2004.tb00024.x

[32] Ostman, P.O., Hellman, M. and Sennerby, L. (2005) Direct Implant Loading in the Edentulous Maxilla Using a Bone Density-Adapted Surgical Protocol and Primary Implant Stability Criteria for Inclusion. Clinical Implant Dentistry and Related Research, 7, S60-S69. http://dx.doi.org/10.1111/j.1708-8208.2005.tb00076.x

[33] Vanden Bogaerde, L., Rangert, B. and Wendelhag, I. (2005) Immediate/Early Function of Branemark System TiUnite Implants in Fresh Extraction Sockets in Maxillae and Posterior Mandibles: An 18-Month Prospective Clinical Study. Clinical Implant Dentistry and Related Research, 7, S121-S130. http://dx.doi.org/10.1111/j.1708-8208.2005.tb00084.X

[34] Zix, J., Kessler-Liechti, G. and Mericske-Stern, R. (2005) Stability Measurements of 1-Stage Implants in the Maxilla by Means of Resonance Frequency Analysis: A Pilot Study. The International Journal of Oral \& Maxillofacial Implants, 20, 747-752.

[35] Abrahamson, I., Berglundh, T., Linder, E., Lang, N.P. and Lindhe, J. (2004) Early Bone Formation Adjacent to Rough and Turned Endosseous Implant Surfaces. An Experimental Study in the Dog. Clinical Oral Implants Research, 15, 381-392. http://dx.doi.org/10.1111/j.1600-0501.2004.01082.x

[36] Masaki, C., Schneider, G.B., Zaharias, R., Seabold, D. and Stanford, C. (2005) Effects of Implant Surface Microtopography on Osteoblast Gene Expression. Clinical Oral Implants Research, 16, 650-656. http://dx.doi.org/10.1111/j.1600-0501.2005.01170.x

[37] Nelson, K., Heberer, S. and Glatzer, C. (2007) Survival Analysis and Clinical Evaluation of Implant-Retained Prostheses in Oral Cancer Resection Patients over a Mean Follow-Up Period of 10 Years. Journal of Prosthetic Dentistry, 98, 405-410. http://dx.doi.org/10.1016/S0022-3913(07)60125-5

[38] Linsen, S.S., Martini, M. and Stark, H. (2012) Long-Term Results of Endosteal Implants Following Radical Oral Cancer Surgery with and without Adjuvant Radiation Therapy. Clinical Implant Dentistry and Related Research, 14, 250-258. http://dx.doi.org/10.1111/j.1708-8208.2009.00248.x 